\begin{tabular}{llcc}
\multicolumn{3}{c}{ Table 1} & \\
& & $\begin{array}{c}\text { Histamine value } \\
(\mu \mathrm{g} / \mathrm{g} \text { wet tissue })\end{array}$ & $\begin{array}{c}\text { Mast cell } \\
\text { count }\end{array}$ \\
Bullfrog & Mesentery & $0 \cdot 19 \pm 0.06$ & ++++ \\
& Tongue & $0 \cdot 04 \pm 0.01$ & +++ \\
Rat & I.iver & $0 \cdot 07 \pm 0.01$ & - \\
& Mesentery & $24 \cdot 8 \pm 4 \cdot 4$ & ++ \\
& Abdominal skin & $29 \cdot 8 \pm 3 \cdot 1$ & ++
\end{tabular}

Proliminary results obtained in the course of a comparative study of various animals in our laboratory suggest that mast cells are free of histamine throughout the teleosts and amphibia and that it is not present below the level of the reptilia.

We thank Professor Hidemasa Yamasaki, Department of Pharmacology, Okayama University Medical School, for his advice and encouragement during this work.

\section{KENCHI TAKAYA}

Tsuneo Fujita

Department of Anatomy,

Okayama University Medical School,

I64 Oka, Olsayama, Japan.

Department of Pharmacology,

KoICHI ENDo

Okayama University Medical School.

Received May 2, 1967.

${ }^{1}$ Fujita, T., and Takaya, K., Z. Zellforsch., 75, 160 (1966).

'Arvy, X., C.R. Soc. Biol. Paris, 149, 528 (1955).

${ }^{3}$ Arvy, L., C.R. Assoc. Anat., 42, Reunion, 217 (1955).

${ }^{4}$ Code, C. F., J. Physiol., 89, 257 (1937).

'Juhlin, L., and Shelley, W., J. Histochem. Cytochem., 14, 525 (1966)

'Falk, B., Acta Physiol. Scand., 56, suppl. 197, 1 (1962).

'Padawer, J., Z. Zellforsch., 75, 178 (1966).

\section{GENETICS}

\section{Haptoglobins, Transferrins and Serum Gamma- globulin Types in Malayan Aborigines}

The Malayan aborigines form a distinet ethnie group which is socially and anthropologically different from the three main population groups in Malaya - the Malays, the Chinese and the Indians. 'The aborigines live mostly in the jungle, follow their own customs and beliefs and have little contact with non-aborigines. They are plagued by diseases, the most common of which are malaria and tubereulosis. Genetically the aborigines are of particular interest. Studies have revealed high frequencies in this population of certain hacmatological abnormalities: haemoglobin $\mathrm{E}$ ranges from 8 to 50 per cent in different groups ${ }^{1}$, glucose-6-phosphate (G-6-P) dehydrogenase deficiency from 8 to 23 per cent ${ }^{1}$, and hereditary ovalocytosis is found in $\mathbf{1 2 . 3}$ per cent of aborigines examined ${ }^{2}$. These high frequencies may be due to malaria or inbreeding or both. We now report the results of a preliminary study of haptoglobins, transferrins and serum gammaglobulin types in Malayan aborigines.

Blood samples obtained from various aborigine groups were frozen and shipped by air to San Francisco. Haptoglobin types were determined by starch-gel electrophoresis by the method of Smithies ${ }^{3}$. A highly sensitive benzidine solution was used to stain the haemoglobin-haptoglobin complex. In those instances when haptoglobin was not detected, the serum sample was run threc times before ahaptoglobinaemia was diagnosed. 'Transferrin types were determined from the same starch gol by the autoradiographic method of Giblett et al. ${ }^{4}$, in which they are identified by the use of radioactive iron-59. At a later stage a method of micropurification, followed by electrophoresis, was also employed ${ }^{5}$. Typing for hereditary gamma-globulin (Gm) groups was performed by the inhibition of agglutination reactions using standard tube systems described by Fudenberg and Kunkel ${ }^{6}$.

Blood from 266 Malayan aborigines, 72 jungle fighters and 194 villagers and aboriginal hospital personnel was examined for haptoglobins. The aborigines were from different junglo areas, and 64 villagers had to be excluded from the study because they were related to persons included. Typo 1 I was found in six aborigines, 2-1 ir
79 , and $2-2$ in 101, and haptoglobin was not detectable in sixteen. The gene frequencies for $\mathrm{Hp}^{1}$ and $\mathrm{Hp}^{2}$ were respectively $0 \cdot 24$ and $0 \cdot 76$. The frequency for haemoglobin $\mathrm{E}$ in the whole group was $34 \cdot 0$ per cent, for G-6-P dehydrogenase deficiency, $\mathbf{1 5 \cdot 7}$ per cent, and for ovalocytosis, $12 \cdot 0$ por cent. Of the sixteen haptoglobin-negative persons, six carried haernoglobin $\mathbf{E}$ and ten did not; two were deficient in G-6-P dehydrogenase and fourteen had normal amounts in the erythrocytes; two had ovalocytosis and fourteen had not; one had malarial parasites and fifteen were uninfected at the time of study. From these data, malaria, haemoglobin $\mathrm{E}$ and $\mathrm{G}$-6-P dehydrogenase deficiency did not seem to be the cause of the high frequency of haptoglobin-negative persons in this population group.

The same serum samples were also studied for transferrins. Among 202 sera from unrelated subjects, 196 contained only Tf $\mathrm{C}$ and six contained Tf CD. The Tf D resembled $\mathrm{Tf} \mathrm{D}_{\mathrm{Chi}}$ and $\mathrm{Tf} \mathrm{D}_{1}$. The exact identity of the Tf $D$ is being studied at the Department of Zoology, University of Texas, Austin. The Tf $D_{\text {Chi }}$ has been found to differ in amino-acid substitution from that of Tf $\mathrm{D}_{1}$ (rof. 7).

The attention of population geneticists has recently been attracted to the examination of hereditary gammaglobulins. The Gin types, because of their typical Mendelian inheritance, have proved useful in both anthropological and genetic studies, and the frequencies of different phenotypes vary greatly from one population to another. The systems for the detection of hereditary $\mathrm{Gm}$ types have steadily increased in number and, like the blood group system, they have become more and more complex. We examined various $\mathrm{Gm}$ factors in the sera from Malayan aborigines, and results were as follows: results of tests for $\mathrm{Gm}$ (a) and (b) on 147 sera from unrelated persons were 99 per cerit positive; of 72 tested for $\mathrm{Gm}$ f, 97 per cent were positive. (Cm x was uniformly negative in 107 sera from unrelated persons, and negative results were also uniformly obtained for Gm-like (Gm-c) activity in 131 sera. This pattern differs from the patterns found in Caucasians, Negroes, Australian aborigines, Japanese and Chinese.

We thank Dr H. E. Sutton for providing a standard Tf $\mathrm{CD}_{\mathrm{Chi}}$ and $\mathrm{Dr}$ E. R. Giblett for standard samples containing $\mathrm{Tf} \mathrm{B}_{2} \mathrm{C}$ and $\mathrm{Tf} \mathrm{CD}_{1}$.

This work was supported by a research grant, and by the University of California International Center for Medical Research and Training with a research grant from the Office of International Research, both from the National Institutes of Health, US Public Health Service. and by a grant from the University of California School of Medicine Committee on Research.

Note added in proof. Since completion of this manuscript, Dr. H. E. Sutton of the Department of Zoology, University of Texas, has reported that our Tf D is Tf $D_{C h}$. We are grateful for his help.

Lte-Injo Luan Fing

The G. W. Hooper Foundation and Department of Epidemiology and International Health,

University of California Medical Center,

San Francisco, California.

\section{J. M. BolToN}

The Aboriginal Hospital, Ulu Gombak, Malaysia.

H. H. FIDENBEKC

Scetion of Hematology and Immunology,

Department of Medicine,

University of California San Franciseo

Medical Center.

Received June 15, 1967.

'Tie-Injo, T. E., and Chin, 3., Nature. 204, 291 (1961).

" Lic-Injo, L. E., Nuture, 208, $1329(1965)$.

${ }^{3}$ Smithies, O., Biochem. J., 71, 585 (1959)

${ }^{4}$ Gibiett, E. K.. Hickman, C. G., and Smithics, O.. Nature, 183, 1589 (1959).

- Iratson, G., A., Sutton, H. F.. Swanson. J., Robinson, A. R., alu Santiana.

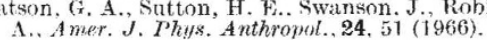

'Fudenterg. H. H., and Kunkel, H. G., ,. Exp. Med., 114, 257 (196!).

T Wang, An-chtau, and Sutton, H. F.. Srienee. 156. 936 (19B6). 